\title{
Practices and Challenges Encountered by Woodcarving Industry in Paete, Laguna: Basis for Sustainability Program
}

\author{
Bayocot, Marydel V. \\ amvbayocot@gmail.com \\ ${ }^{a}$ Laguna College of Business and Arts (LCBA), Calamba City, Philippines \\ ${ }^{b}$ Laguna State Polytechnic University (LSPU), Philippines
}

\begin{abstract}
This research aimed to determine the level of practices of sustainability initiatives and challenges encountered by the woodcarving industry in Paete, Laguna. The researcher used the descriptive correlational approach and collected data using a formal instrument. The data was collected randomly from 153 respondents of registered business owners, active woodcarvers, and the Local Government Unit employees who play a major role in the woodcarving sector in the area. For statistical treatment, the four-point Likert Scale, simple mean, ANOVA, and Pearson Correlation (Pearson's r) were used. The results revealed that sustainable initiatives in terms of economic, social, and environmental dimensions are being practiced to sustain the woodcarving industry in Paete, Laguna. It was found out that there is no significant difference in the assessment of the three groups of respondents in terms of economic and environmental dimensions but the aspect of the social dimension. The local industry believes that the problem in wood supply is rarely being encountered as compared to the challenges in the aspects of human capital, financial, market, technological advancement, cooperative management and governance, and public awareness. Thus, it shows that the level of practice of economic, social, and environmental initiatives has a direct relationship with the level of challenges encountered by the industry. Further, this paper attempts to contribute to the sustainability of the woodcarving business in the locality.
\end{abstract}

Keywords: sustainability; woodcarving; sustainable initiatives; industry challenges; Paete

\section{Introduction}

Due to climate change and enormous global environmental concerns, the business industries in all aspects use the term sustainability in their ongoing concern. Sustainability is the capability of being sustained, maintained at length without interruption or weakening. It focuses on meeting the needs of the present without compromising the ability of future generations to meet their needs. The concept is composed of the three pillars of economic, environmental, and social, otherwise known as profit, planet, and people (Grant, 2019). The sustainable business strategy considers the coordination and management of the economic, social, and environmental demands in management operation.

According to Business Models for Sustainability: Origins, Present Research, and Future Avenues published by Schaltegger et.al. (2015), genuine and substantive sustainable development of the industry cannot be achieved through usual approaches on the technological process and product innovation, philanthropy, and corporate social responsibility, the key is by initiating a focus on sustainability management. Businesses have to be always mindful of the complementing effects and trade-offs among these pillars. All the same, inclusive support from the key players - the government, the private sector, the civil society in terms of education, policies on economic, social, and environmental resource management is necessary to ensure that everyone is aware, conscious, and compliant. 
Rezaee (2016) mentioned that sustainable development for organizations is not only providing products and services to satisfy the needs of the customer but also operating in a socially responsible manner that is not jeopardizing the environment and by presenting reliable and transparent sustainability reports. Consequently, environmental performance shows how effectively the organization deals with ecological challenges for future generations. Khattak et al. (2018) added that the successful implementation of sustainability practices is vital for organizational survival and competitive advantage. Therefore, the challenge is for decision-makers to manage resources not just at a point in time but rather across time in all disciplines, from ecology to art and agriculture to architecture. Likewise, Haanaes (2016) cited that sustainability is becoming more important for many organizations across all industries.

One of the oldest industries in the world is wood carving Gaille (2018). Thus, one of the most renowned wood carving industries in the Philippines is located in the municipality of Paete, Laguna. The town is known for its one-of-a-kind artistry and world-class wood carving not only in the local scene but in many parts of the world. The wood carving industry has brought benefits to woodcarvers, which include income generation, creation of employment, preservation of culture and tradition, and promotion of the tourism industry. However, its full potential has not been fully tapped, and there is a need to come up with measures that can be put in place to improve the wood carving sector (Muthini, 2017).

Paete was proclaimed as the "Carving Capital of the Philippines" through Presidential Proclamation No. 809, series of 2005. The Paetenians' source of income and livelihood was mainly from woodcarving. Nevertheless, there is the issue of the log ban, the dwindling numbers of carvers involved in the craft, and the modernization of different industries viewed as some of the constraints in sustaining the wood carving in the locality. Paete is the "Carving Capital of the Philippines," but the question is - until when?

Subsequently, Lestari et al. (2016) mentioned in their study on the island of Bali - Indonesia that the small craft industry of wood carving is an addition to the tourism industry. The study indicates that the craft of wood carving is very feasible and has the potential to be more empowered.

In this study, the proponent assessed the level of practice of sustainability initiatives and the challenges encountered by the industry players in sustaining the woodcarving in the municipality of Paete, Laguna. Valuing the woodcarving not just as a source of living but part of the legacy of the people that should be handed down through generations.

\section{Theoretical/Conceptual Framework}

The study is anchored on the United Nations 2030 Agenda for Sustainable Development "The UNESCO Sustainable Development Goals (SDG) model (2015)". For the industry to become sustainable, this seamless principle is absolute to adopt in sustaining the wood carving business, considering the three (3) essential pillars for development. Industry strategy for creating long-term value by considering the economic, social, and environmental factors in the business and adopting sustainable action that fosters the industry's longevity.

In support of the above theory, the study will also be complemented with concepts about the wood carving industry in different parts of the world by various authors. According to Baraoidan (2019), Muthini (2017), and Adu-Agyem et al., (2014), the human capital or the dwindling number of woodcarvers, lack of wood supply, lack of financial support, lack of competitive local and international market, technological advancement, lack of cooperative management and governance, and insufficient public awareness, among others, are the challenges facing the wood carving industry.

\section{Hypotheses}

The study tested the following null hypothesis at a .05 level of significance: 
a. There is no significant difference in the assessments of the business owners, woodcarvers, and Local Government Unit employees on the level of practice of sustainability initiatives of the woodcarving industry in Paete, Laguna.

b. There is no significant difference in the assessments of the business owners, woodcarvers, and Local Government Unit employees on the level of challenges encountered by the wood carving industry in Paete, Laguna.

c. There is no significant relationship between the level of practices of sustainability initiatives and the challenges encountered by the wood carving industry in Paete, Laguna.

\section{Scope and Delimitation}

The researcher limited its discussion on the level of practice of sustainability initiatives in terms of social, economic, and environmental aspects and challenges encountered in sustaining the wood carving business in the municipality of Paete, Laguna as assessed by the local woodcarvers, the business owners, and the employees of the Local Government Unit (LGU) employees.

\section{Methodology}

The study used the descriptive correlational research design to assess the relationship between the practices of sustainable initiatives and the challenges encountered by the wood carving industry in Paete, Laguna. The researcher devised the research instrument where the content was validated by the panel of evaluators together with external experts in the field of research. The reliability of the tool was tested through the use of Cronbach's Alpha test and pilot testing to 30 respondents before implementing the actual data gathering procedure. To limit the sample size, the G-Power Calculator was used. The data was collected from 153 respondents composed of registered business owners, active woodcarvers, and the Local Government Unit employees. For the statistical treatment of data, the researcher made use of Mean, ANOVA, and Pearson Product-Moment Correlation Coefficient.

\section{Results and Discussion}

\section{Table 1.1}

Assessment of the Business Owners, Woodcarvers, and Employees of the Local Government Unit on the Level of Practice of Sustainability Initiatives in Paete, Laguna in terms of Economic Dimension

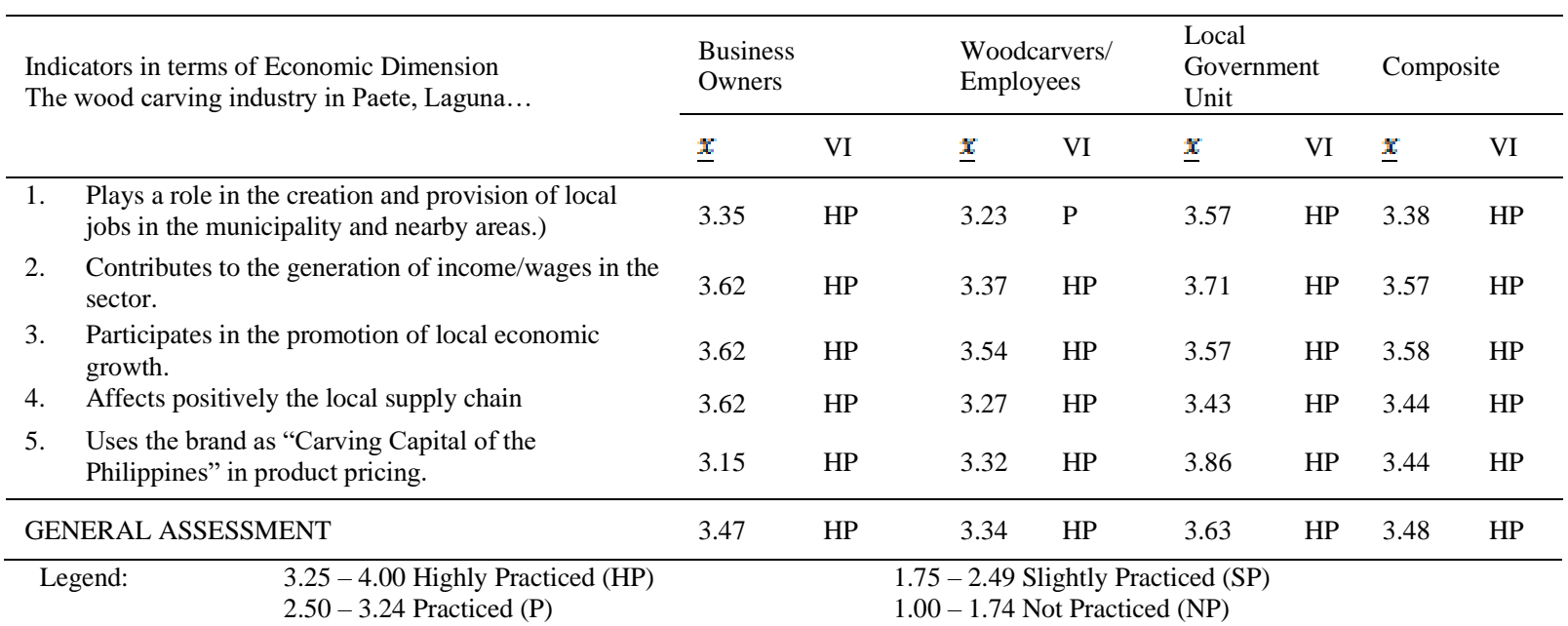

Table 1.1 shows the assessment of the business owners, woodcarvers, and the employees of the Local Government Unit on the level of practice of sustainability initiatives in the wood carving industry in 
Paete, Laguna in terms of economic dimension. The general assessment was 3.48 which was verbally interpreted as "Highly Practice". All indicators were verbally interpreted as Highly Practiced. The indicator "Participates in the promotion of local economic growth." has the highest computed composite mean of 3.58 while the indicator "Plays a role in the creation and provision of local jobs in the municipality and nearby areas." has the least computed mean of 3.38 .

This implied that the wood carving industry in Paete, Laguna highly practiced sustainability initiatives in terms of the economic dimension as assessed by the three groups of respondents. The local industry participates in the promotion of local economic growth. The result of the assessment is concurrent with what was cited by England (2018), saying that the local economies are the only "true" economies where developmental work is vital. In a market economy, the mechanisms of economic development are primarily private businesses that create wealth and jobs in the locality. However, these private businesses cannot succeed without a favorable business environment and setting to thrive and flourish.

Table 1.2

Assessment of the Business Owners, Woodcarvers, and Employees of the Local Government Unit on the Level of Practice of Sustainability Initiatives in Paete, Laguna in terms of Social Dimension

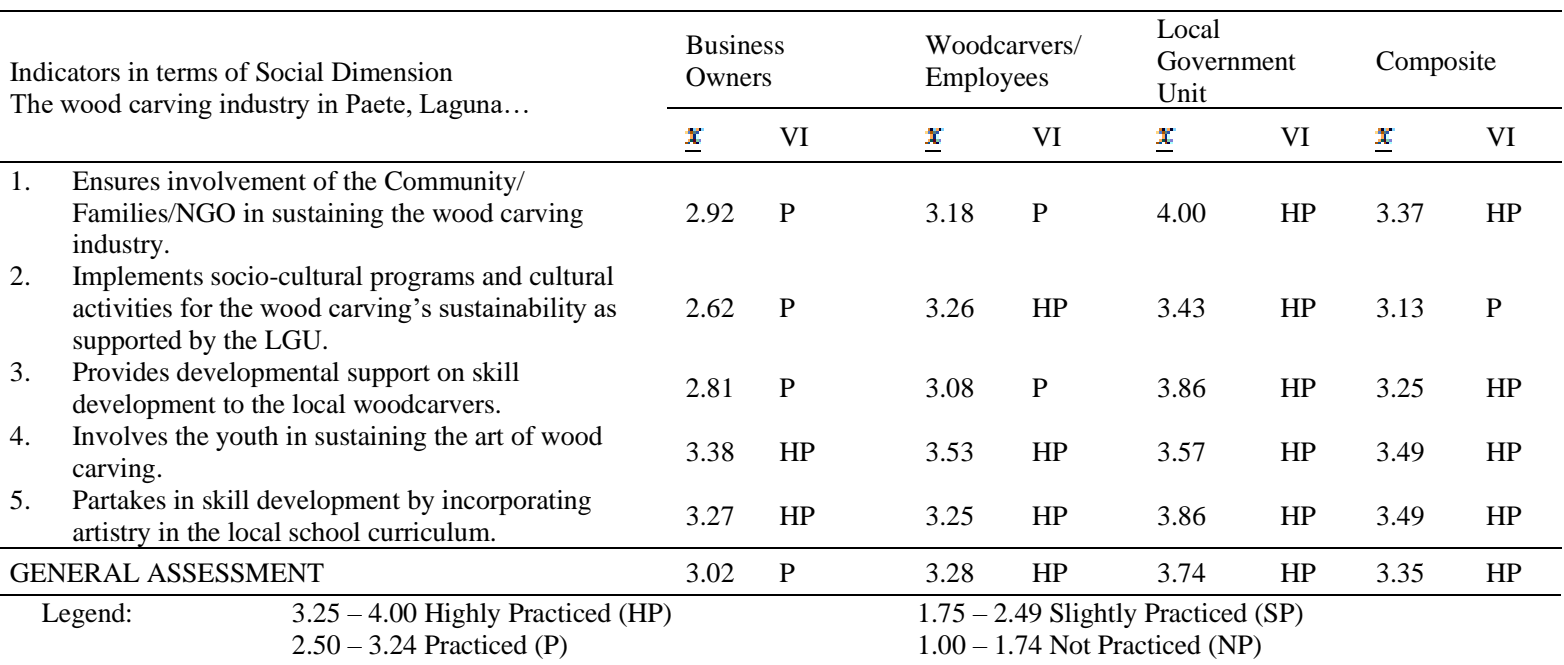

As shown in Table 1.2, the general assessment of the business owners, woodcarvers, and employees of the Local Government Unit on the level of practice of sustainability initiatives in terms of social dimension was 3.35 and was verbally interpreted as "Highly Practiced". The indicators "Involves the youth in sustaining the art of wood carving." and "Partakes in the skill development by incorporating the artistry in the local school curriculum." has the highest computed mean of 3.49 which were verbally interpreted as Highly Practiced while the indicator "Implements socio-cultural programs and cultural activities for the wood carving sustainability as supported by the LGU." has the least computed composite mean of 3.13 which was verbally interpreted as Practiced.

This shows that the wood carving industry in Paete, Laguna highly practices sustainability initiatives in terms of the social dimension as assessed by the three groups of respondents. The carving industry involves the youth in sustaining the art of wood carving and partakes in their skill development by incorporating the artistry in the local school curriculum. As mentioned by Rezaee (2016), aside from economic performance that reflects the long-term profitability and financial sustainability of the business, social performance is also a measure of how well the business translates its social goals into practices and how it fulfills its social responsibility. 
Table 1.3

Assessment of the Business Owners, Woodcarvers, and Employees of the Local Government Unit on the Level of Practice of Sustainability Initiatives in Paete, Laguna in terms of Environmental Dimension

\begin{tabular}{|c|c|c|c|c|c|c|c|c|}
\hline \multirow{2}{*}{$\begin{array}{l}\text { Indicators in terms of Environment Dimension } \\
\text { The wood carving industry in Paete, Laguna... }\end{array}$} & \multicolumn{2}{|c|}{$\begin{array}{l}\text { Business } \\
\text { Owners }\end{array}$} & \multicolumn{2}{|c|}{$\begin{array}{l}\text { Woodcarvers/E } \\
\text { mployees }\end{array}$} & \multicolumn{2}{|c|}{$\begin{array}{l}\text { Local } \\
\text { Government } \\
\text { Unit }\end{array}$} & \multicolumn{2}{|c|}{ Composite } \\
\hline & $\underline{x}$ & VI & $\underline{x}$ & VI & $\underline{x}$ & VI & $\underline{x}$ & VI \\
\hline $\begin{array}{l}\text { 1. Ensures awareness of the stakeholders in the environmental } \\
\text { effect of the wood carving industry on global warming. }\end{array}$ & 2.73 & $\mathrm{P}$ & 2.88 & $\mathrm{P}$ & 3.29 & HP & 2.97 & $\mathrm{P}$ \\
\hline 2. Uses recycled woods for production. & 2.62 & $\mathrm{P}$ & 3.10 & $\mathrm{P}$ & 3.29 & $\mathrm{HP}$ & 3.00 & $\mathrm{P}$ \\
\hline Uses other raw materials or wood-like goods for carving. & 2.69 & $\mathrm{P}$ & 3.09 & $\mathrm{P}$ & 3.00 & $\mathrm{P}$ & 2.93 & $\mathrm{P}$ \\
\hline $\begin{array}{l}\text { 4. Implements environmental management programs to sustain the } \\
\text { wood carving industry as initiated by the LGU. }\end{array}$ & 2.77 & $\mathrm{P}$ & 2.98 & $\mathrm{P}$ & 3.43 & $\mathrm{P}$ & 3.06 & $\mathrm{P}$ \\
\hline $\begin{array}{l}\text { 5. Utilizes the waste (sawdust, wood shavings, etc.) to produce } \\
\text { other significant products to promote environmental } \\
\text { conservation. }\end{array}$ & 2.88 & $\mathrm{P}$ & 3.03 & $\mathrm{P}$ & 2.34 & SP & 2.78 & $\mathrm{P}$ \\
\hline GENERAL ASSESSMENT & 2.74 & $\mathrm{P}$ & 3.02 & $\mathrm{P}$ & 3.09 & $\mathrm{P}$ & 2.95 & $\mathrm{P}$ \\
\hline $\begin{array}{ll}\text { Legend: } & 3.25-4.00 \text { Highly Practiced }(\mathrm{HP}) \\
& 2.50-3.24 \text { Practiced }(\mathrm{P})\end{array}$ & & $\begin{array}{l}75-2 \\
00-\end{array}$ & $\begin{array}{l}\text { Slight } \\
\text { Not P }\end{array}$ & $\begin{array}{l}\text { acticec } \\
\text { ced }(\mathrm{N})\end{array}$ & & & & \\
\hline
\end{tabular}

Table 1.3 showed the assessment of the business owners, woodcarvers, and employees of the Local Government Unit on the level of practice of sustainability initiatives of the wood carving industry practices in Paete, Laguna in terms of environmental dimension. The general assessment was 2.95 which was verbally interpreted as "Practiced". All indicators were verbally interpreted as Practiced. The indicator "Implements environmental management programs to sustain the wood carving industry as initiated by the LGU." has the highest computed composite mean of 3.06 while the indicator "Utilizes the waste (sawdust, wood shavings, etc.) to produce other significant products to promote environmental conservation." has the least computed mean of 2.78.

This shows that the wood carving industry in Paete, Laguna practices sustainability initiatives in terms of environmental dimension. The carving industry, particularly the Local Government Unit, is implementing programs to protect the environment for the industry's source of raw materials and sustainability. The result concurred with the study of Mangra et al., (2017), which cited that manufacturing firms who know themselves as a big contributor to the carbon footprint accumulation have made strides in protecting the environment. In many countries, environmental management system implementation, although a voluntary action, managed to convince, not only through the financial benefits obtained but also by increasing credibility to attract investors and beneficiaries. 
Table 2.1

Test of Significant Difference on the Assessment of Business Owners, Woodcarvers, and Employees of the Local Government Unit on the Wood Carving Industry's Level of Practice of Sustainability Initiatives in Paete, Laguna in terms of Economic, Social, and Environmental Dimensions

\begin{tabular}{|c|c|c|c|c|c|c|c|c|}
\hline & & $\begin{array}{l}\text { Sum of } \\
\text { squares }\end{array}$ & $\mathrm{df}$ & $\begin{array}{l}\text { Mean } \\
\text { square }\end{array}$ & F Ratio & Sig. & Decision & Remarks \\
\hline Economic Dimension & $\begin{array}{l}\text { Between Groups } \\
\text { Within Groups } \\
\text { Total } \\
\end{array}$ & $\begin{array}{l}.800 \\
36.924 \\
37.724 \\
\end{array}$ & $\begin{array}{l}2 \\
150 \\
152 \\
\end{array}$ & $\begin{array}{l}.400 \\
.246\end{array}$ & 1.625 & .200 & $\begin{array}{l}\text { Accept } \\
\mathrm{H}_{\mathrm{o}}\end{array}$ & Not Significant \\
\hline Social Dimension & $\begin{array}{l}\text { Between Groups } \\
\text { Within Groups } \\
\text { Total }\end{array}$ & $\begin{array}{l}3.234 \\
40.403 \\
43.637 \\
\end{array}$ & $\begin{array}{l}2 \\
150 \\
152 \\
\end{array}$ & $\begin{array}{l}1.617 \\
.269\end{array}$ & 6.003 & .003 & Reject $\mathrm{H}_{\mathrm{o}}$ & Significant \\
\hline $\begin{array}{l}\text { Environmental } \\
\text { Dimension }\end{array}$ & $\begin{array}{l}\text { Between Groups } \\
\text { Within Groups } \\
\text { Total }\end{array}$ & $\begin{array}{l}1.748 \\
46.497 \\
48.245\end{array}$ & $\begin{array}{l}2 \\
150 \\
152\end{array}$ & $\begin{array}{l}.874 \\
.310\end{array}$ & 2.819 & .063 & $\begin{array}{l}\text { Accept } \\
\mathrm{H}_{\mathrm{o}}\end{array}$ & Not Significant \\
\hline
\end{tabular}

Level of significance 0.05

As shown in Table 2.1, the generated computed probability values of Economic and Environment dimensions were .200 and .063 which were greater than the level of significance of 0.05 ; thus, the null hypothesis is accepted. Therefore, there is no significant difference among the responses of the three groups of respondents on the level of practice of sustainability initiatives in the wood carving industry in terms of Economic Dimension and Environmental Dimension. This means that the business owners, woodcarvers, and employees of the Local Government Unit have the same perception of the woodcarving industry's sustainability initiative practices in Paete, Laguna in these two pillars of sustainable development.

On the other hand, the generated computed probability value for the social dimension was .003 which was less than the level of significance of 0.05; thus, the null hypothesis is rejected. Therefore, there is a significant difference among the responses of the three groups of respondents on the level of practice of sustainability initiatives in the woodcarving industry in terms of the Social Dimension. This can be concluded that the business owners, woodcarvers, and employees of the Local Government Unit of the wood carving industry in Paete, Laguna have different points of view on the level of practice of sustainability initiatives when it comes to social aspects.

The result coincides with the view of Bansal and Jardine (2015) who mentioned that sustainability is the balance between resource usage and supplies over time to be economically productive. Sustainability assures intergenerational equity or availability of resources to flourish the economy where resources are coming from the environment. And, when the resources match the earth's capacity to regenerate adequate future supply, the systems will remain balanced indefinitely that will eventually lead to the ability to meet society's needs, it may not be visible at the moment but in the future. 
Table 3.1

Assessment of the Business Owners, Woodcarvers, and Employees of the Local Government Unit on the Level of Challenges Encountered by the Woodcarving Business in Paete, Laguna in terms of Human Capital

\begin{tabular}{|c|c|c|c|c|c|c|c|c|}
\hline \multirow[t]{2}{*}{$\begin{array}{l}\text { Indicators in terms of Human Capital } \\
\text { The woodcarvers in Paete, Laguna... }\end{array}$} & \multicolumn{2}{|c|}{$\begin{array}{l}\text { Business } \\
\text { Owners }\end{array}$} & \multicolumn{2}{|c|}{$\begin{array}{l}\text { Woodcarvers/ } \\
\text { Employees }\end{array}$} & \multicolumn{2}{|c|}{$\begin{array}{l}\text { Local } \\
\text { Government } \\
\text { Unit }\end{array}$} & \multicolumn{2}{|c|}{ Composite } \\
\hline & $\underline{x}$ & VI & $\underline{x}$ & VI & $\underline{x}$ & VI & $\underline{x}$ & VI \\
\hline 1. $\quad$ Possess limited skills and ability in carving. & 1.88 & SE & 2.06 & SE & 2.86 & $\mathrm{RE}$ & 2.77 & $\mathrm{RE}$ \\
\hline $\begin{array}{l}\text { 2. Declines in number including those interested in this } \\
\text { field. }\end{array}$ & 1.73 & $\mathrm{AE}$ & 2.18 & SE & 3.14 & RE & 2.35 & SE \\
\hline $\begin{array}{l}\text { 3. Acquire limited capacity building to produce quality } \\
\text { products. }\end{array}$ & 1.58 & $\mathrm{AE}$ & 2.05 & SE & 3.14 & RE & 2.26 & SE \\
\hline $\begin{array}{l}\text { 4. Lacks understanding with regards to the artistry and } \\
\text { product designs }\end{array}$ & 1.46 & $\mathrm{AE}$ & 2.13 & SE & 3.14 & RE & 2.25 & SE \\
\hline 5. Have no ability to diversify their carving skills. & 1.85 & $\mathrm{AE}$ & 2.71 & SE & 3.00 & $\mathrm{RE}$ & 2.52 & $\mathrm{RE}$ \\
\hline GENERAL ASSESSMENT & 1.70 & $\mathrm{AE}$ & 2.23 & SE & 3.06 & RE & 2.33 & SE \\
\hline $\begin{array}{ll}\text { Legend: } & 3.25-4.00 \text { Not Encountered (NE) } \\
& 2.50-3.24 \text { Rarely Encountered (RE) }\end{array}$ & & & & & cou & (SE) & & \\
\hline
\end{tabular}

As shown in Table 3.1, the general assessment of business owners, woodcarvers, and employees of the Local Government Unit on the level of challenges being encountered by the wood carving business in Paete, Laguna in terms of Human Capital was 2.33 and was verbally interpreted as "Sometimes Encountered". The indicator "Possess limited skills and ability in carving." has the highest computed mean of 2.77 which was verbally interpreted as Rarely Encountered while the indicator "Lacks understanding with regards to the artistry and product designs." has the least computed composite mean of 2.25 which was verbally interpreted as Rarely Encountered.

It can be concluded that the wood carving industry in Paete, Laguna sometimes encountered the aspect of human capital as a challenge to the industry. Nevertheless, the industry rarely considers as a problem the lack of understanding of the woodcarvers on the industry's artistry.

On that note, human capital is important for jobs that require manual skills; people particularly pay for artistic products as a credit to the manual labor done and to the name behind the craft. Guia (2016), mentioned in her study on the Marketing and Economic Viability of the Carving Industry in Paete, Laguna, that attention must be given, among others, to the craft design, quality of product, and craftsmanship. According to her, these factors bring positive effects and contribute to the success of the industry. Thus, quality is the primary strength of the woodcraft of Paete, Laguna which is an output of manual labor exerted on the product. Likewise, Gao and Yu (2018) cited that the technical abilities of the people are important aspects that must be enhanced and maintained. Even in the case of digital production, the production output still depends on the technical level of operators. 
Table 3.2

Assessment of the Business Owners, Woodcarvers, and Employees of the Local Government Unit on the Level of Challenges Encountered by the Woodcarving Business in Paete, Laguna in terms of Wood Supply

\begin{tabular}{|c|c|c|c|c|c|c|c|c|}
\hline \multirow[t]{2}{*}{$\begin{array}{l}\text { Indicators in terms of Wood Supply } \\
\text { The wood carving industry in Paete, Laguna... }\end{array}$} & \multicolumn{2}{|c|}{$\begin{array}{l}\text { Business } \\
\text { Owners }\end{array}$} & \multicolumn{2}{|c|}{$\begin{array}{l}\text { Woodcarvers/ } \\
\text { Employees }\end{array}$} & \multicolumn{2}{|c|}{$\begin{array}{l}\text { Local } \\
\text { Government } \\
\text { Unit }\end{array}$} & \multicolumn{2}{|c|}{ Composite } \\
\hline & $\underline{x}$ & VI & $\underline{x}$ & VI & $\underline{x}$ & VI & $\underline{x}$ & VI \\
\hline 1. Encounters scarce wood supply affecting the industry. & 2.31 & SE & 2.54 & RE & 3.00 & $\mathrm{RE}$ & 2.62 & $\mathrm{RE}$ \\
\hline $\begin{array}{l}\text { 2. Experiences limited production due to the high cost of } \\
\text { raw material/ wood. }\end{array}$ & 2.12 & SE & 2.90 & $\mathrm{RE}$ & 2.86 & RE & 2.62 & $\mathrm{RE}$ \\
\hline 3. Utilizes deteriorating quality of wood supply. & 2.27 & SE & 2.95 & $\mathrm{RE}$ & 2.86 & $\mathrm{RE}$ & 2.69 & $\mathrm{RE}$ \\
\hline $\begin{array}{l}\text { 4. Experiences a dwindling number in the wood variety } \\
\text { available for the craft that affects the industry. }\end{array}$ & 2.54 & $\mathrm{RE}$ & 2.90 & $\mathrm{RE}$ & 2.71 & $\mathrm{RE}$ & 2.72 & $\mathrm{RE}$ \\
\hline $\begin{array}{l}\text { 5. Encounters difficulty due to the log ban } \\
\text { implementation. }\end{array}$ & 2.08 & SE & 2.52 & $\mathrm{RE}$ & 2.14 & SE & 2.25 & SE \\
\hline GENERAL ASSESSMENT & 2.26 & SE & 2.76 & RE & 2.71 & $\mathrm{RE}$ & 2.58 & $\mathrm{RE}$ \\
\hline $\begin{array}{ll}\text { Legend: } & 3.25-4.00 \text { Not Encountered (NE) } \\
& 2.50-3.24 \text { Rarely Encountered (RE) }\end{array}$ & & & $\begin{array}{l}75-2 . \\
00-1\end{array}$ & $\begin{array}{l}\text { Somet } \\
\text { Alway }\end{array}$ & $\begin{array}{l}\text { Enco } \\
\text { count }\end{array}$ & $\begin{array}{l}\text { tered } \\
\text { d (AF }\end{array}$ & & \\
\hline
\end{tabular}

Table 3.2 shows the assessment of business owners, woodcarvers, and employees of the Local Government Unit on the level of challenges being encountered by the wood carving industry in Paete, Laguna in terms of wood supply. The results showed a general assessment of 2.58 and were verbally interpreted as "Rarely Encountered". The indicators "Experiences a dwindling number in the wood variety available for the craft that affects the industry." has the highest computed mean of 2.72 which was verbally interpreted as Rarely Encountered while the indicator "Encounters difficulty due to the log ban implementation." has the least computed composite mean of 2.25 which was verbally interpreted as Sometimes Encountered.

The wood carving industry in Paete, Laguna rarely encountered the challenge of wood supply. The industry players much consider the issues on log ban implementation over the dwindling variety of wood supply. This was mentioned in the study of Lestari et al., (2016), that obstacles faced by craftsmen at the level of the production process are the shortage of wood supply or raw material coming from the island of Bali, Indonesia. The decrease in production capacity is a result of limited resources for executing production. In connection, it is estimated that the logging ban would reduce China's wood production by about 50 million m3, which would impact China's wood supply in the short term as reported by Clever (2017) in the Gain Report - Global Agricultural Information Network. 
Table 3.3

Assessment of the Business Owners, Woodcarvers, and Employees of the Local Government Unit on the Level of Challenges Encountered by the Woodcarving Business in Paete, Laguna in terms of Financial

\begin{tabular}{|c|c|c|c|c|c|c|c|c|}
\hline \multirow[t]{2}{*}{$\begin{array}{l}\text { Indicators in terms of Financial } \\
\text { The wood carving industry in Paete, Laguna... }\end{array}$} & \multicolumn{2}{|c|}{$\begin{array}{l}\text { Business } \\
\text { Owners }\end{array}$} & \multicolumn{2}{|c|}{$\begin{array}{l}\text { Woodcarvers/ } \\
\text { Employees }\end{array}$} & \multicolumn{2}{|c|}{$\begin{array}{l}\text { Local } \\
\text { Government } \\
\text { Unit }\end{array}$} & \multicolumn{2}{|c|}{ Composite } \\
\hline & $\underline{x}$ & VI & $\underline{x}$ & VI & $\underline{x}$ & VI & $\underline{x}$ & VI \\
\hline $\begin{array}{l}\text { 1. Experiences withholding business growth due to } \\
\text { insufficient capital of the business owners. }\end{array}$ & 1.54 & $\mathrm{AE}$ & 2.73 & $\mathrm{RE}$ & 2.71 & $\mathrm{RE}$ & 2.33 & SE \\
\hline $\begin{array}{l}\text { 2. Has limited production capacity due to a lack of funds for } \\
\text { the business. }\end{array}$ & 1.77 & SE & 2.75 & $\mathrm{RE}$ & 2.71 & $\mathrm{RE}$ & 2.41 & SE \\
\hline $\begin{array}{l}\text { 3. Has limited financial assistance as extended by the } \\
\text { government to sustain the industry }\end{array}$ & 1.77 & $\mathrm{SE}$ & 2.81 & $\mathrm{RE}$ & 2.57 & $\mathrm{RE}$ & 2.38 & SE \\
\hline $\begin{array}{l}\text { 4. Does not contribute to the income generation of the } \\
\text { municipality. }\end{array}$ & 2.12 & SE & 2.83 & $\mathrm{RE}$ & 2.86 & $\mathrm{RE}$ & 2.60 & $\mathrm{RE}$ \\
\hline 5. Provides insufficient income from the business/occupation. & 2.04 & SE & 2.93 & RE & 2.43 & SE & 2.47 & SE \\
\hline GENERAL ASSESSMENT & 1.85 & SE & 2.81 & $\mathrm{RE}$ & 2.66 & $\mathrm{RE}$ & 2.44 & SE \\
\hline $\begin{array}{ll}\text { Legend: } & 3.25-4.00 \text { Not Encountered (NE) } \\
& 2.50-3.24 \text { Rarely Encountered (RE) }\end{array}$ & & & $\begin{array}{l}2.49 \\
1.74\end{array}$ & & untere & & & \\
\hline
\end{tabular}

As shown in Table 3.3, the general assessment of business owners, woodcarvers, and employees of the Local Government Unit on the level of challenges being encountered by the wood carving industry in Paete, Laguna in the Financial aspect was 2.44 and verbally interpreted as "Sometimes Encountered". The indicators "Does not contribute to income generation of the municipality." has the highest computed mean of 2.60 which were verbally interpreted as Rarely Encountered while the indicator "Experiences withholding business growth due to insufficient capital of the business owners." has the least computed composite mean of 2.33 which was verbally interpreted as Rarely Encountered.

Based on the above-mentioned findings of the study, the Financial aspect is sometimes encountered by the industry. It only means that businesses are withheld from growing due to insufficient funds for capitalization. Nevertheless, it shows that the wood carving industry in Paete, Laguna contributes to the income generation of the municipality. Further, this particular aspect is a challenge associated with the traditional wood carving industry aside from the scarcity of wood. Limited capital was also mentioned as a threat in the study of Lestari (2016) in the SWOT Analysis made in the wood carving business in Bali, Indonesia.

Table 3.4

Assessment of Business Owners, Woodcarvers, and Employees of the Local Government Unit on the Level of Challenges Encountered by the Woodcarving Business in Paete, Laguna in terms of Market

\begin{tabular}{|c|c|c|c|c|c|c|c|c|}
\hline \multirow[t]{2}{*}{$\begin{array}{l}\text { Indicators in terms of Market } \\
\text { The wood carving industry of Paete, Laguna... }\end{array}$} & \multicolumn{2}{|c|}{$\begin{array}{l}\text { Business } \\
\text { Owners }\end{array}$} & \multicolumn{2}{|c|}{$\begin{array}{l}\text { Woodcarvers/ } \\
\text { Employees }\end{array}$} & \multicolumn{2}{|c|}{$\begin{array}{l}\text { Local } \\
\text { Government } \\
\text { Unit }\end{array}$} & \multicolumn{2}{|c|}{ Composite } \\
\hline & $\underline{x}$ & VI & $\underline{x}$ & VI & $\underline{x}$ & VI & $\underline{x}$ & VI \\
\hline 1. Has limited access to the local market & 1.58 & $\mathrm{AE}$ & 2.07 & SE & 3.71 & $\mathrm{NE}$ & 2.12 & SE \\
\hline 2. Has limited access to the international market. & 1.62 & $\mathrm{AE}$ & 2.47 & SE & 3.00 & $\mathrm{RE}$ & 2.36 & SE \\
\hline $\begin{array}{l}\text { 3. Has limited numbers of market } \\
\text { players/participants. }\end{array}$ & 1.69 & $\mathrm{AE}$ & 2.48 & SE & 2.57 & $\mathrm{RE}$ & 2.25 & SE \\
\hline $\begin{array}{l}\text { 4. Has a limited market opportunity for small wood } \\
\text { carving enterprises. }\end{array}$ & 1.96 & SE & 2.62 & $\mathrm{RE}$ & 3.00 & $\mathrm{RE}$ & 2.50 & $\mathrm{RE}$ \\
\hline $\begin{array}{l}\text { 5. Does not dominate other wood carving markets in } \\
\text { the country. }\end{array}$ & 1.81 & SE & 2.19 & SE & 2.57 & $\mathrm{RE}$ & 2.19 & SE \\
\hline GENERAL ASSESSMENT & 1.73 & $\mathrm{AE}$ & 2.35 & SE & 2.77 & $\mathrm{RE}$ & 2.28 & SE \\
\hline $\begin{array}{ll}\text { Legend: } & 3.25-4.00 \text { Not Encountered (NE) } \\
& 2.50-3.24 \text { Rarely Encountered (RE) }\end{array}$ & & & $\begin{array}{l}1.75-2 \\
1.00-1\end{array}$ & $\begin{array}{l}\text { Some } \\
\text { Alwa }\end{array}$ & $\begin{array}{l}\text { es Enc } \\
\text { Encour }\end{array}$ & $\begin{array}{l}\text { ered } \\
\text { d (AF }\end{array}$ & & \\
\hline
\end{tabular}


As shown in Table 3.4, the general assessment of business owners, woodcarvers, and employees of the Local Government Unit on the level of challenges being encountered by the wood carving industry in Paete, Laguna in terms of Market was 2.28 and verbally interpreted as "Sometimes Encountered". The indicators "Has the limited market opportunity for small wood carving enterprises." has the highest computed mean of 2.50 which were verbally interpreted as Rarely Encountered while the indicator "Has limited access to the local market." has the least computed composite mean of 2.12 which was verbally interpreted as Sometimes Encountered.

The result shows that the wood carving industry sometimes experiences difficulty in accessing the market. This is very particular in the area of gaining access in the local market which garnered the lowest score. Moreover, this is indeed a challenge for the industry as the business owners' group gave this particular variable the lowest rating which was deemed to be their most common dilemma. Likewise, this was supported by the study of Adu-Agyem et. Al (2014) who further elaborated that another constraint for the wood carving industry is the limited market share. Insufficient markets for the finished wood-carved products have also been a big challenge to the woodcarvers in Ghana.

Table 3.5

Assessment of the Business Owners, Woodcarvers, and Employees of the Local Government Unit on the Level of Challenges Encountered by the Woodcarving Business in Paete, Laguna in terms of Technological Advancement

\begin{tabular}{|c|c|c|c|c|c|c|c|c|}
\hline \multirow[t]{2}{*}{$\begin{array}{l}\text { Indicators in terms of Technological Advancement } \\
\text { The wood carving industry in Paete, Laguna... }\end{array}$} & \multicolumn{2}{|c|}{$\begin{array}{l}\text { Business } \\
\text { Owners }\end{array}$} & \multicolumn{2}{|c|}{$\begin{array}{l}\text { Woodcarvers/E } \\
\text { mployees }\end{array}$} & \multicolumn{2}{|c|}{$\begin{array}{l}\text { Local } \\
\text { Government } \\
\text { Unit }\end{array}$} & \multicolumn{2}{|c|}{ Composite } \\
\hline & $\underline{x}$ & VI & $\underline{x}$ & VI & $\underline{x}$ & VI & $\underline{x}$ & VI \\
\hline $\begin{array}{l}\text { 1. Has no appropriate technology to improve wood carving } \\
\text { products' quality. }\end{array}$ & 2.00 & SE & 1.97 & SE & 2.86 & $\mathrm{RE}$ & 2.27 & SE \\
\hline $\begin{array}{l}\text { 2. Does not ensure stakeholder knowledge of technology to } \\
\text { speed up wood carving production. }\end{array}$ & 2.00 & SE & 2.06 & SE & 2.43 & SE & 2.16 & SE \\
\hline $\begin{array}{l}\text { 3. Has no available modern equipment \& machinery } \\
\text { applicable to the industry to improve production. }\end{array}$ & 1.58 & $\mathrm{AE}$ & 1.98 & SE & 2.43 & SE & 2.00 & SE \\
\hline $\begin{array}{l}\text { 4. Do not utilize the industry's technology for maximum } \\
\text { production. }\end{array}$ & 2.96 & $\mathrm{RE}$ & 2.09 & $\mathrm{SE}$ & 2.43 & SE & 2.49 & SE \\
\hline 5. Do not utilize technology for promotion and marketing. & 2.00 & SE & 2.52 & $\mathrm{RE}$ & 2.57 & $\mathrm{RE}$ & 2.36 & SE \\
\hline GENERAL ASSESSMENT & 2.11 & SE & 2.12 & SE & 2.54 & $\mathrm{RE}$ & 2.26 & SE \\
\hline $\begin{array}{ll}\text { Legend: } & 3.25-4.00 \text { Not Encountered (NE) } \\
& 2.50-3.24 \text { Rarely Encountered (RE) }\end{array}$ & $\begin{array}{l}1.75-2 \\
1.00-1\end{array}$ & $\begin{array}{l}\text { Son } \\
\text { All }\end{array}$ & $\begin{array}{l}\text { mes } \\
\text { s En }\end{array}$ & $\begin{array}{l}\text { ntere } \\
\text { red }(1\end{array}$ & & & & \\
\hline
\end{tabular}

As shown in Table 3.5, the general assessment of business owners, woodcarvers, and employees of the Local Government Unit on the level of challenges being encountered by the wood carving industry in Paete, Laguna in terms of Technological Advancement was 2.26, verbally interpreted as "Sometimes Encountered". The indicators “Does not utilize the industries/technology for maximum production." has the highest computed mean of 2.49 which was verbally interpreted as Sometimes Encountered while the indicator "Has no available modern equipment \& machinery applicable to the industry to improve production." has the least computed composite mean of 2.00 which was verbally interpreted as Sometimes Encountered.

The above-mentioned findings in Technological Advancement are sometimes encountered as a challenge to the wood carving industry in Paete, Laguna, particularly in the area of having available modern equipment and machinery applicable to the industry to improve production. This challenge may be applied to the woodcraft items that are usually produced in bulk, like give-aways and small souvenir items that can be produced with the aid of machines and equipment to improve and fast-track the production process. 
This is similar to what Rilong and Boqiang (2016) revealed in their study about measuring agricultural energy efficiency, that productivity has improved in general due to the advancement of technology. Consequently, the application of technology has a positive effect, as it increases efficiency. They have mentioned that technological innovation and managerial efficiency should be promoted to increase efficiency which is of great significance for the sustainable development of the sector.

Table 3.6

Assessment of the Business Owners, Woodcarvers, and Employees of the Local Government Unit on the Level of Challenges Encountered by the Woodcarving Business in Paete, Laguna in terms of Developmental Support

\begin{tabular}{|c|c|c|c|c|c|c|c|c|}
\hline \multirow[t]{2}{*}{$\begin{array}{l}\text { Indicators in terms of Developmental Support } \\
\text { The wood carving industry in Paete, Laguna... }\end{array}$} & \multicolumn{2}{|c|}{$\begin{array}{l}\text { Business } \\
\text { Owners }\end{array}$} & \multicolumn{2}{|c|}{$\begin{array}{l}\text { Woodcarvers/ } \\
\text { Employees }\end{array}$} & \multicolumn{2}{|c|}{$\begin{array}{l}\text { Local } \\
\text { Government } \\
\text { Unit }\end{array}$} & \multicolumn{2}{|c|}{ Composite } \\
\hline & $\underline{x}$ & VI & $\underline{x}$ & VI & $\underline{x}$ & VI & $\underline{x}$ & VI \\
\hline $\begin{array}{l}\text { 1. Does not provide training and skill development to the } \\
\text { woodcarvers. }\end{array}$ & 3.00 & RE & 1.90 & SE & 3.14 & $\mathrm{RE}$ & 2.68 & $\mathrm{RE}$ \\
\hline $\begin{array}{l}\text { 2. Does not provide business-related training to the } \\
\text { business owners. }\end{array}$ & 2.85 & RE & 2.03 & SE & 3.14 & RE & 2.62 & $\mathrm{RE}$ \\
\hline 3. Is not supported by the tourism industry. & 1.81 & $\mathrm{SE}$ & 2.49 & $\mathrm{SE}$ & 2.43 & SE & 2.24 & $\mathrm{SE}$ \\
\hline $\begin{array}{l}\text { 4. Has limited programs to recognize local } \\
\text { woodcarvers/artists. }\end{array}$ & 1.77 & SE & 2.58 & RE & 3.00 & RE & 2.45 & SE \\
\hline $\begin{array}{l}\text { 5. Does not implement programs to encourage local wood } \\
\text { carving businesses and woodcarvers. }\end{array}$ & 1.92 & SE & 2.27 & SE & 2.71 & RE & 2.30 & SE \\
\hline GENERAL ASSESSMENT & 2.27 & SE & 2.25 & SE & 2.89 & RE & 2.47 & SE \\
\hline $\begin{array}{ll}\text { Legend: } & 3.25-4.00 \text { Not Encountered (NE) } \\
& 2.50-3.24 \text { Rarely Encountered (RE) }\end{array}$ & & & $0-1.7$ & ways & counte & & & \\
\hline
\end{tabular}

As shown in Table 3.6, the general assessment of business owners, woodcarvers, and employees of the Local Government Unit on the level of challenges being encountered by the wood carving industry in Paete, Laguna in terms of Developmental Support was 2.47 which is verbally interpreted as "Sometimes Encountered". The indicators "Does not provide training and skill development to the woodcarvers." has the highest computed mean of 2.68 which were verbally interpreted as Rarely Encountered while the indicator "Is not supported by the tourism industry." has the least computed composite mean of 2.24 which was verbally interpreted as Sometimes Encountered.

Challenges in the area of developmental support are sometimes being encountered by the wood carving industry in Paete, Laguna. The results implied that among the indicators of the said variable, it is the support of the tourism industry that the respondents considered as the most challenging area. The livelihood industry in small communities is usually flourishing by way of tourist attractions in many parts of the world. According to Marhaeni (2019), the aspect of support mechanisms empowers and energizes people to be able to move independently. This constraint was also discovered in the same study in Bali, Indonesia, - lack of developmental support from the Department of Tourism (Government) in the marketing process and the allocation of means of handicraft products exhibition. 
Table 3.7

Assessment of Business Owners, Woodcarvers, and Employees of the Local Government Unit on the Level of Challenges

Encountered by the Woodcarving Business in Paete, Laguna in terms of Cooperative Management \& Governance

\begin{tabular}{|c|c|c|c|c|c|c|c|c|}
\hline \multirow[t]{2}{*}{$\begin{array}{l}\text { Indicators in terms of Cooperative Management \& Governance } \\
\text { The LGU in Paete, Laguna... }\end{array}$} & \multicolumn{2}{|c|}{$\begin{array}{l}\text { Business } \\
\text { Owners }\end{array}$} & \multicolumn{2}{|c|}{$\begin{array}{l}\text { Woodcarvers/E } \\
\text { mployees }\end{array}$} & \multicolumn{2}{|c|}{$\begin{array}{l}\text { Local } \\
\text { Government } \\
\text { Unit }\end{array}$} & \multicolumn{2}{|c|}{ Composite } \\
\hline & $\underline{x}$ & VI & $\underline{x}$ & VI & $\underline{x}$ & VI & $\underline{x}$ & VI \\
\hline $\begin{array}{l}\text { 1. Does not initiate building a stable network for the wood carving } \\
\text { industry. }\end{array}$ & 1.92 & SE & 1.96 & SE & 2.57 & $\mathrm{RE}$ & 2.15 & SE \\
\hline $\begin{array}{l}\text { 2. Does not promote the participation of all stakeholders to uplift } \\
\text { the wood carving industry. }\end{array}$ & 1.77 & SE & 2.05 & SE & 2.14 & SE & 1.99 & SE \\
\hline $\begin{array}{l}\text { 3. Do not exert effort on improving the artistry to sustain the wood } \\
\text { carving sector. }\end{array}$ & 1.65 & $\mathrm{AE}$ & 2.29 & SE & 2.43 & SE & 2.12 & SE \\
\hline $\begin{array}{l}\text { 4. Does not encourage collaborative effort between the LGU, } \\
\text { businesses, and woodcarvers to sustain the industry. }\end{array}$ & 1.92 & SE & 2.36 & SE & 3.00 & $\mathrm{RE}$ & 2.43 & SE \\
\hline $\begin{array}{l}\text { 5. Does not implement effective management and governance } \\
\text { towards the industry's success. }\end{array}$ & 1.92 & SE & 1.91 & SE & 3.00 & $\mathrm{RE}$ & 2.28 & SE \\
\hline GENERAL ASSESSMENT & 1.84 & SE & 2.11 & SE & 2.63 & RE & 2.19 & SE \\
\hline $\begin{array}{ll}\text { Legend: } & 3.25-4.00 \text { Not Encountered (NE) } \\
& 2.50-3.24 \text { Rarely Encountered (RE) }\end{array}$ & & $\begin{array}{l}1.75 \\
1.00\end{array}$ & 1.74 & $\begin{array}{l}\text { imes } \\
\text { s En }\end{array}$ & tere & & & \\
\hline
\end{tabular}

As shown in Table 3.7, the general assessment of business owners, woodcarvers, and employees of the Local Government Unit on the level of challenges being encountered by the wood carving industry in Paete, Laguna in terms of Cooperative Management and Governance was 2.19 and verbally interpreted as "Sometimes Encountered". The indicators "Does not encourage collaborative effort between the LGU, businesses, and woodcarvers to sustain the industry." has the highest computed mean of 2.43 which were verbally interpreted as Sometimes Encountered while the indicator "Does not promote the participation of all stakeholders to uplift the wood carving industry." has the least computed composite mean of 1.99 which was verbally interpreted as Sometimes Encountered.

The results of the study show that the area of Cooperative Management and Governance is sometimes being encountered as a challenge by the wood carving industry in Paete, Laguna. It means that the industry players perceived this as a challenge expecting the LGU in promoting the participation of all stakeholders to uplift the wood carving industry. As a basis to eliminate this industry challenge, Battaglia et al. (2015) mentioned that cooperative sustainability is a new way of communicating with employees and members to develop new opportunities to consolidate the relationships with other stakeholders with whom the organization might share strategies and objectives. This is particular for local suppliers, local communities, institutions, and representatives of civil society. Likewise, England (2018) mentioned that local governments and other public sectors have a major role to play in helping to establish and maintain a favorable business environment condition for industries. 
Table 3.8

Assessment of the Business Owners, Woodcarvers, and Employees of the Local Government Unit on the Level of Challenges Encountered by the Woodcarving Business in Paete, Laguna in terms of Public Awareness

\begin{tabular}{|c|c|c|c|c|c|c|c|c|}
\hline \multirow[t]{2}{*}{$\begin{array}{l}\text { Indicators in terms of Public Awareness } \\
\text { The wood carving industry in Paete, Laguna... }\end{array}$} & \multicolumn{2}{|c|}{$\begin{array}{l}\text { Business } \\
\text { Owners }\end{array}$} & \multicolumn{2}{|c|}{$\begin{array}{l}\text { Woodcarvers/ } \\
\text { Employees }\end{array}$} & \multicolumn{2}{|c|}{$\begin{array}{c}\text { Local } \\
\text { Government } \\
\text { Unit } \\
\end{array}$} & \multicolumn{2}{|c|}{ Composite } \\
\hline & $\underline{x}$ & VI & $\underline{x}$ & VI & $\underline{x}$ & VI & $\underline{x}$ & VI \\
\hline $\begin{array}{l}\text { 1. Does not ensure public knowledge of the importance of the } \\
\text { wood carving industry as part of Paete's heritage. }\end{array}$ & 1.77 & SE & 2.66 & $\mathrm{RE}$ & 3.29 & $\mathrm{RE}$ & 2.57 & $\mathrm{RE}$ \\
\hline $\begin{array}{l}\text { 2. Do not disseminate information about the industry's plans } \\
\text { and programs. }\end{array}$ & 1.77 & SE & 2.33 & SE & 2.57 & $\mathrm{RE}$ & 2.22 & SE \\
\hline $\begin{array}{l}\text { 3. Does not implement an effective communication channel to } \\
\text { promote the participation of the industry stakeholders. }\end{array}$ & 1.58 & $\mathrm{AE}$ & 2.21 & SE & 2.57 & $\mathrm{RE}$ & 2.12 & SE \\
\hline $\begin{array}{l}\text { 4. Does not ensure the involvement of the young generation in } \\
\text { preserving the craft and woodcarving artistry. }\end{array}$ & 1.77 & SE & 2.49 & SE & 3.43 & $\mathrm{NE}$ & 2.56 & $\mathrm{RE}$ \\
\hline $\begin{array}{l}\text { 5. Does not implement an effective campaign to sustain the } \\
\text { title "Carving Capital of the Philippines". }\end{array}$ & 1.85 & SE & 2.58 & RE & 3.14 & $\mathrm{RE}$ & 2.52 & $\mathrm{RE}$ \\
\hline GENERAL ASSESSMENT & 1.75 & SE & 2.45 & SE & 3.00 & $\mathrm{RE}$ & 2.40 & SE \\
\hline $\begin{array}{l}3.25-4.00 \text { Not Encountered (NE) } \\
2.50-3.24 \text { Rarely Encountered (RE) }\end{array}$ & & & & & & $\begin{array}{l}\text { d (SE) } \\
\text { (E) }\end{array}$ & & \\
\hline
\end{tabular}

As shown in Table 3.8, the general assessment of business owners, woodcarvers, and employees of the Local Government Unit on the level of challenges being encountered by the wood carving industry in Paete, Laguna in terms of Public Awareness was 2.40 and verbally interpreted as "Sometimes Encountered". The indicators "Does not ensure public knowledge on the importance of the wood carving industry as part of Paete's heritage." has the highest computed mean of 2.57 which were verbally interpreted as Rarely Encountered while the indicator "Does not implement an effective communication channel to promote the participation of the industry stakeholders." has the least computed composite mean of 2.12 which was verbally interpreted as Sometimes Encountered.

The results implied that the wood carving industry in Paete, Laguna considered having the public aware of the industry as a challenge. It can be concluded that the industry is not implementing an effective communication channel to promote the participation of all the industry's stakeholders. This coincided with the results as shown in the previous table, Table 3.7, which indicated that there is a challenge in terms of participation of all stakeholders to uplift the wood carving industry that could be manifested through poor communication among the members. The aspect of public awareness was reinforced in the study of Soma et al. (2016). It was mentioned that governing through information is made possible through increased information sharing and interaction, increased cooperation, and empowerment. Informational governance reflects on how increased information sharing and interaction can transform societies towards more collaboration, empowerment, self-organization, private governing, and interconnectedness. 
Table 4.1

Test of Significant Difference on the Assessment of the Business Owners, Woodcarvers, and Employees of the Local Government Unit on the Level of Challenges Encountered by the Wood Carving Industry in Paete, Laguna in terms of Human Capital, Wood Supply, Financial, Market, Technological Advancement, developmental Support, Cooperative Management \& Governance, and Public Awareness

\begin{tabular}{|c|c|c|c|c|c|c|c|c|}
\hline & & $\begin{array}{l}\text { Sum of } \\
\text { squares }\end{array}$ & df & $\begin{array}{l}\text { Mean } \\
\text { square }\end{array}$ & F Ratio & Sig. & Decision & Remarks \\
\hline Human Capital & $\begin{array}{l}\text { Between Groups } \\
\text { Within Groups } \\
\text { Total }\end{array}$ & $\begin{array}{l}11.634 \\
34.872 \\
46.506 \\
\end{array}$ & $\begin{array}{l}2 \\
150 \\
152 \\
\end{array}$ & $\begin{array}{l}5.817 \\
.232\end{array}$ & 25.021 & .000 & Reject $\mathrm{H}_{\mathrm{o}}$ & Significant \\
\hline Wood Supply & $\begin{array}{l}\text { Between Groups } \\
\text { Within Groups } \\
\text { Total }\end{array}$ & $\begin{array}{l}5.357 \\
61.354 \\
66.711 \\
\end{array}$ & $\begin{array}{l}2 \\
150 \\
152 \\
\end{array}$ & $\begin{array}{l}2.678 \\
.409\end{array}$ & 6.548 & .002 & Reject $\mathrm{H}_{\mathrm{o}}$ & Significant \\
\hline Financial & $\begin{array}{l}\text { Between Groups } \\
\text { Within Groups } \\
\text { Total }\end{array}$ & $\begin{array}{l}19.923 \\
60.105 \\
80.029 \\
\end{array}$ & $\begin{array}{l}2 \\
150 \\
152 \\
\end{array}$ & $\begin{array}{l}9.962 \\
.401\end{array}$ & 24.860 & .000 & Reject $\mathrm{H}_{\mathrm{o}}$ & Significant \\
\hline Market & $\begin{array}{l}\text { Between Groups } \\
\text { Within Groups } \\
\text { Total }\end{array}$ & $\begin{array}{l}10.083 \\
91.010 \\
101.092 \\
\end{array}$ & $\begin{array}{l}2 \\
150 \\
152 \\
\end{array}$ & $\begin{array}{l}5.041 \\
.607\end{array}$ & 8.309 & .000 & Reject $\mathrm{H}_{\mathrm{o}}$ & Significant \\
\hline $\begin{array}{l}\text { Technological } \\
\text { Advancement }\end{array}$ & $\begin{array}{l}\text { Between Groups } \\
\text { Within Groups } \\
\text { Total }\end{array}$ & $\begin{array}{l}1.197 \\
60.970 \\
62.167 \\
\end{array}$ & $\begin{array}{l}2 \\
150 \\
152 \\
\end{array}$ & $\begin{array}{l}.598 \\
.406\end{array}$ & 1.472 & .233 & Accept $\mathrm{H}_{\mathrm{o}}$ & $\begin{array}{l}\text { Not } \\
\text { Significant }\end{array}$ \\
\hline $\begin{array}{l}\text { Developmental } \\
\text { Support }\end{array}$ & $\begin{array}{l}\text { Between Groups } \\
\text { Within Groups } \\
\text { Total }\end{array}$ & $\begin{array}{l}2.653 \\
47.323 \\
49.975\end{array}$ & $\begin{array}{l}2 \\
150 \\
152\end{array}$ & $\begin{array}{l}1.326 \\
.315\end{array}$ & 4.204 & .017 & Reject $\mathrm{H}_{\mathrm{o}}$ & Significant \\
\hline $\begin{array}{l}\text { Cooperative } \\
\text { Management and } \\
\text { Governance }\end{array}$ & $\begin{array}{l}\text { Between Groups } \\
\text { Within Groups } \\
\text { Total }\end{array}$ & $\begin{array}{l}3.741 \\
68.014 \\
71.755 \\
\end{array}$ & $\begin{array}{l}2 \\
150 \\
152 \\
\end{array}$ & $\begin{array}{l}1.870 \\
.453\end{array}$ & 4.125 & .018 & Reject $\mathrm{H}_{\mathrm{o}}$ & Significant \\
\hline $\begin{array}{l}\text { Public } \\
\text { Awareness }\end{array}$ & $\begin{array}{l}\text { Between Groups } \\
\text { Within Groups } \\
\text { Total }\end{array}$ & $\begin{array}{l}13.671 \\
52.324 \\
65.995\end{array}$ & $\begin{array}{l}2 \\
150 \\
152 \\
\end{array}$ & $\begin{array}{l}6.836 \\
.349\end{array}$ & 19.596 & .000 & Reject $\mathrm{H}_{\mathrm{o}}$ & Significant \\
\hline
\end{tabular}

Level of significance 0.05

As shown in Table 4.1, the generated computed probability values of Human Capital, Wood Supply, Financial, Market, Developmental Support, Cooperative Management \& Governance, and Public Awareness were $.000, .002, .000, .000, .017, .018$, and .000 respectively which were less than the level of significance of 0.05 ; thus, the null hypothesis is rejected. Therefore, there is a significant difference among the responses of the three groups of respondents on the level of challenges encountered by the wood carving industry in Paete, Laguna.

The results above means that the business owners, woodcarvers, and employees of the Local Government Unit have different experiences on the level of challenges encountered by the woodcarving industry in Paete, Laguna in terms of human capital, wood supply, financial, market, developmental support, cooperative management \& governance, and public awareness.

On the other hand, the generated computed probability value on the aspect of technological advancement was .233 which was greater than the level of significance of 0.05 ; thus, the null hypothesis is accepted. Therefore, there is no significant difference among the responses of the three groups of respondents on the level of challenges encountered in terms of technological advancement. The business owners, woodcarvers, and employees of the Local Government Unit have the same perceptions on technological advancement as one of the challenges encountered by the wood carving industry in Paete, Laguna.

As the three groups have mostly different perceptions on the challenges being encountered by the wood carving industry, Bansal and Jardine (2014) mentioned that it is crucial for mainstreaming sustainability in strategy as it is more than just a fad. Alongside sustainability is a new paradigm that acknowledges the complexity of systems and imbalances among factors and members that may undermine and affect 
sustainability. Therefore, the challenges are for decision-makers to manage resources not just at one point in time but rather across time in all disciplines.

Table 5.1

Significant Relationship between the Level of Practice of Sustainability Initiatives and Challenges Encountered by the Wood Carving Industry in Paete, Laguna

\begin{tabular}{|c|c|c|c|c|c|}
\hline $\begin{array}{l}\text { Sustainability } \\
\text { Initiative } \\
\text { Practices }\end{array}$ & $\begin{array}{l}\text { Challenges in Sustaining the Woodcarving } \\
\text { Industry }\end{array}$ & r value & $\mathrm{P}$-value & Decision & Remarks \\
\hline \multirow{8}{*}{$\begin{array}{l}\text { Economic } \\
\text { Dimension }\end{array}$} & Human Capital & .076 & .349 & Accept $\mathrm{H}_{\mathrm{o}}$ & Not Significant \\
\hline & Wood Supply & $.566^{* *}$ & .000 & Reject $\mathrm{H}_{\mathrm{o}}$ & Significant \\
\hline & Financial & .065 & .424 & Accept $\mathrm{H}_{\mathrm{o}}$ & Not Significant \\
\hline & Market & $.376^{* *}$ & .000 & Reject $\mathrm{H}_{\mathrm{o}}$ & Significant \\
\hline & Technological Advancement & $.369 * *$ & .000 & Reject $\mathrm{H}_{\mathrm{o}}$ & Significant \\
\hline & Developmental Support & $.273 * *$ & .001 & Reject $\mathrm{H}_{\mathrm{o}}$ & Significant \\
\hline & Cooperative Management and Governance & $.368 * *$ & .000 & Reject $\mathrm{H}_{\mathrm{o}}$ & Significant \\
\hline & Public Awareness & $.363^{* *}$ & .000 & Reject $\mathrm{H}_{\mathrm{o}}$ & Significant \\
\hline \multirow{8}{*}{$\begin{array}{l}\text { Social } \\
\text { Dimension }\end{array}$} & Human Capital & $.276^{* *}$ & .001 & Reject $\mathrm{H}_{\mathrm{o}}$ & Significant \\
\hline & Wood Supply & $.638 * *$ & .000 & Reject $\mathrm{H}_{\mathrm{o}}$ & Significant \\
\hline & Financial & $.159 * *$ & .008 & Reject $\mathrm{H}_{\mathrm{o}}$ & Significant \\
\hline & Market & $.399 * *$ & .000 & Reject $\mathrm{H}_{\mathrm{o}}$ & Significant \\
\hline & Technological Advancement & .108 & .183 & Accept $\mathrm{H}_{\mathrm{o}}$ & Not Significant \\
\hline & Developmental Support & $.225^{* *}$ & .005 & Reject $\mathrm{H}_{\mathrm{o}}$ & Significant \\
\hline & Cooperative Management and Governance & $.327 * * *$ & .000 & Reject $\mathrm{H}_{\mathrm{o}}$ & Significant \\
\hline & Public Awareness & $.440 * * *$ & .000 & Reject $\mathrm{H}_{\mathrm{o}}$ & Significant \\
\hline \multirow{8}{*}{$\begin{array}{l}\text { Environmental } \\
\text { Dimension }\end{array}$} & Human Capital & .134 & .099 & Accept $\mathrm{H}_{\mathrm{o}}$ & Not Significant \\
\hline & Wood Supply & $.712 * *$ & .000 & Reject $\mathrm{H}_{\mathrm{o}}$ & Significant \\
\hline & Financial & $.328 * *$ & .000 & Reject $\mathrm{H}_{\mathrm{o}}$ & Significant \\
\hline & Market & $.490 * *$ & .000 & Reject $\mathrm{H}_{\mathrm{o}}$ & Significant \\
\hline & Technological Advancement & $.296 * *$ & .000 & Reject $\mathrm{H}_{\mathrm{o}}$ & Significant \\
\hline & Developmental Support & $.380 * *$ & .000 & Reject $\mathrm{H}_{\mathrm{o}}$ & Significant \\
\hline & Cooperative Management and Governance & $.312 * *$ & .000 & Reject $\mathrm{H}_{\mathrm{o}}$ & Significant \\
\hline & Public Awareness & $.520^{* *} *$ & .000 & Reject $\mathrm{H}_{\mathrm{o}}$ & Significant \\
\hline
\end{tabular}

**Correlational at the level $0.01 \quad *$ Correlational at the level 0.05 (Two-tailed)

As shown in Table 5.1 above, the $r$ values of most of the variables were interpreted as low to moderately positive correlation to correlate the level of practice of sustainability initiatives (economic dimension) and challenges encountered the wood carving industry (wood supply, market, technological advancement, developmental support, cooperative management \& governance, and public awareness) and the computed probability values were less than the level of significant $(p<0.05)$; thus, the null hypothesis is rejected. The result shows that there is a significant relationship between the dependent and independent variables.

It can be concluded that the level of practice of sustainability initiatives particularly the economic dimension has a significant relationship with challenges encountered by the wood carving industry specifically on wood supply, market, technological advancement, developmental support, cooperative management \& governance, and public awareness. 
Moreover, the $r$ values of most of the variables were interpreted as with low to moderately positive correlation as to correlate sustainability initiative practices (social dimension) and challenges in sustaining the wood carving industry (human capital, wood supply, financial, market, developmental support, cooperative management \& governance, and public awareness) and the computed probability values were less than the level of significant $(\mathrm{p}<0.05)$; thus, the null hypothesis is rejected. The result shows that there is a significant relationship between the dependent and independent variables.

This shows that the level of practice of sustainability initiatives particularly the social dimension has a significant relationship with challenges encountered by the wood carving industry specifically on human capital, wood supply, financial, market, developmental support, cooperative management \& governance, and public awareness.

Furthermore, the $r$ values of most of the variables were interpreted as low to highly positive correlation as to correlate the level of practice of sustainability initiatives (environmental dimension) and challenges encountered by the wood carving industry (wood supply, financial, market, technological advancement, developmental support, cooperative management \& governance, and public awareness) and the computed probability values were less than the level of significant $(\mathrm{p}<0.05)$; thus, the null hypothesis is rejected. The result shows that there is a significant relationship between the dependent and independent variables.

Thus, the level of practice of sustainability initiatives particularly the environmental dimension has a significant relationship with challenges encountered by the wood carving industry. The sustainability initiative practices in environmental aspects have a significant relationship with the challenges encountered by the wood carving industry specifically the wood supply, financial, market, developmental support, cooperative management \& governance, and public awareness. In general, the level of practice of sustainability initiatives is significantly related to the challenges encountered by the wood carving industry in Paete, Laguna.

Every industry has inherent challenges that can be alleviated through mitigating actions and circumstances. Despite implementation and practicing sustainable initiatives in the economic, social, and environmental aspects, challenges are emerging due to different factors. The main challenge of sustainable development is the need to balance the cost and benefit of development in terms of economic, social, and environmental facets. In a greater view, the challenges to sustainable development must be tackled together for promoting sustainable development (Shekhawat, 2020).

\section{Recommendation}

Based on the results of the study, the researcher proposed a set of strategies and actions to further sustain the woodcarving industry in Paete, Laguna. Likewise, the output of this study is attached as Appendix A - The Proposed Sustainability Program.

The woodcarving industry players may further implement sustainable economic, social, and environmental initiatives and programs for the continuous development of the local industry. For the LGU, it may make the tree planting program a regular frequency as part of the commitment of the Municipality to give back and in sustaining the main source of raw materials for the industry. The LGU may implement enhancement on the programs to combat environmental degradation and climate change and be one of the leading Local Government Units initiating forest management. For the challenges of the sector, the industry players may promote programs to manage and control the risk of declining numbers of people involved in the industry and artistry of woodcarving.

Likewise, activities that will further enhance the understanding of the members may be conducted. The Local Government Unit may further encourage the business owners to sustain their businesses and attract investors through providing business incentive programs and aids. Linkages and partnerships in the local and international market scene may also be enhanced through collaborations, joining trade fairs, and industry forums. A collaborative project may also be developed with other government agencies/NGOs for funding 
and developing appropriate machinery/equipment for the mass production of specific woodcraft items. The stakeholders of Paete, Laguna may develop a platform where the products of the Municipality can be streamlined in a bigger channel/online.

The Local Government Unit may enhance its annual program by regularly conducting an information drive/campaign to increase awareness of the public on the importance of sustaining the woodcarving industry in the Municipality as a source of livelihood, a heritage of the town, and as a legacy for the future generation. The Local Government Unit may adapt the proposed enhancement on the sustainability program developed by the researcher to further sustain and develop the local woodcarving industry. Lastly, further researches may explore the holistic cost and benefit of the woodcarving businesses, particularly the impact of the industry on the environment.

Appendix A

The Proposed Sustainability Program

\begin{tabular}{|c|c|c|c|c|c|c|}
\hline $\begin{array}{c}\text { Key Results } \\
\text { |Area/Areas } \\
\text { of Concern }\end{array}$ & Objectives & Strategies/Activities & $\begin{array}{c}\text { Time } \\
\text { Frame }\end{array}$ & $\begin{array}{l}\text { Person } \\
\text { Involved }\end{array}$ & Budget & $\begin{array}{l}\text { Success } \\
\text { Indicator }\end{array}$ \\
\hline $\begin{array}{l}\text { Economic, } \\
\text { Social, and } \\
\text { Environment }\end{array}$ & $\begin{array}{l}\text { To sustain the } \\
\text { wood carving } \\
\text { industry in the } \\
\text { municipality }\end{array}$ & $\begin{array}{l}\text {-Further enhance the } \\
\text { implementation of related } \\
\text { programs on economic, social, } \\
\text { and environmental aspects of the } \\
\text { wood carving industry. } \\
\text {-Continuously implement related } \\
\text { initiatives. }\end{array}$ & Continuous & $\begin{array}{l}\text {-Community } \\
\text {-Local } \\
\text { Government } \\
\text { Unit } \\
\text {-Business } \\
\text { Owners }\end{array}$ & $\begin{array}{l}\text { Local } \\
\text { Fund }\end{array}$ & $\begin{array}{l}\text { Woodcarving } \\
\text { industry's } \\
\text { contribution } \\
\text { to the GDP }\end{array}$ \\
\hline $\begin{array}{l}\text { Human } \\
\text { Capital }\end{array}$ & $\begin{array}{l}\text { To increase } \\
\text { and sustain the } \\
\text { number of } \\
\text { people } \\
\text { involved in the } \\
\text { wood carving } \\
\text { industry }\end{array}$ & $\begin{array}{l}\text { TRAINING/CAPABILITY } \\
\text { ENHANCEMENT PROGRAM } \\
\text {-Conduct activities that will } \\
\text { further enhance the understanding } \\
\text { of the members with regards to } \\
\text { the artistry and product design. } \\
\text {-Involve in the training of those in } \\
\text { woodcarving industry practice } \\
\text { and those who have potential and } \\
\text { are interested in the field. }\end{array}$ & $\begin{array}{l}\text { At least } \\
\text { annually }\end{array}$ & $\begin{array}{l}\text {-Community } \\
\text {-Local } \\
\text { Government } \\
\text { Unit } \\
\text {-Business } \\
\text { Owners }\end{array}$ & & $\begin{array}{l}20 \% \text { increase } \\
\text { in the number } \\
\text { of } \\
\text { woodcarvers }\end{array}$ \\
\hline $\begin{array}{l}\text { Wood } \\
\text { Supply }\end{array}$ & $\begin{array}{l}\text {-To sustain the } \\
\text { wood supply } \\
\text {-To combat } \\
\text { environment } \\
\text { degradation/ } \\
\text { climate change }\end{array}$ & $\begin{array}{l}\text { CONTINUOUS TREE } \\
\text { PLANTING } \\
\text {-Involve the residents of the } \\
\text { municipality in tree planting of } \\
\text { different varieties and species of } \\
\text { wood. } \\
\text {-Coordinate the Program with } \\
\text { DENR. LGU and NGOs. }\end{array}$ & $\begin{array}{l}\text { All year } \\
\text { round }\end{array}$ & $\begin{array}{l}\text {-Community } \\
\text {-Local } \\
\text { Government } \\
\text { Unit } \\
\text {-NGOs }\end{array}$ & & $\begin{array}{l}-20 \% \text { increase } \\
\text { in production } \\
\text { and capacity } \\
-20 \% \text { s } \\
\text { increase in the } \\
\text { utilization of } \\
\text { wood supply } \\
\text { and variety }\end{array}$ \\
\hline Financial & $\begin{array}{l}\text {-To assist in } \\
\text { the financial } \\
\text { aspect } \\
\text {-To increase } \\
\text { business / } \\
\text { capitalist }\end{array}$ & $\begin{array}{l}\text { INCENTIVE PROGRAM } \\
\text { Provide incentive programs that } \\
\text { will encourage local businesses to } \\
\text { sustain the industry (ex: tax } \\
\text { incentives, seed fund, registration } \\
\text { discounts, and assistance, etc.) }\end{array}$ & $\begin{array}{l}\text { All year } \\
\text { round }\end{array}$ & $\begin{array}{l}\text {-Local } \\
\text { Government } \\
\text { Unit } \\
\text {-Business } \\
\text { Owners } \\
\text {-National } \\
\text { Government }\end{array}$ & & $\begin{array}{l}-20 \% \text { increase } \\
\text { in the number } \\
\text { of registered } \\
\text { wood carving } \\
\text { businesses } \\
-1 \text { to } 2 \\
\text { additional } \\
\text { local/ foreign } \\
\text { investors }\end{array}$ \\
\hline
\end{tabular}




\begin{tabular}{|c|c|c|c|c|c|}
\hline Market & $\begin{array}{l}\text { To increase } \\
\text { market } \\
\text { visibility }\end{array}$ & $\begin{array}{l}\text { PARTNERSHIP/LINKAGES } \\
\text {-Build linkages through local and } \\
\text { international collaborations. } \\
\text {-Enhance and strengthen } \\
\text { community-related programs by } \\
\text { seeking support from the National } \\
\text { Government and other } \\
\text { government/private agencies to } \\
\text { expand the market }\end{array}$ & $\begin{array}{l}\text { All year } \\
\text { round }\end{array}$ & $\begin{array}{l}\text {-Community } \\
\text {-Business } \\
\text { Owners } \\
\text {-Local } \\
\text { Government } \\
\text { Unit } \\
\text {-National } \\
\text { Government } \\
\text {-Department } \\
\text { of Trade and } \\
\text { Industry } \\
\text {-Department } \\
\text { of Tourism }\end{array}$ & $\begin{array}{l}50 \% \text { increased } \\
\text { visibility of } \\
\text { the product in } \\
\text { the local and } \\
\text { international } \\
\text { market scene }\end{array}$ \\
\hline Technology & $\begin{array}{l}\text { To establish } \\
\text { efficient and } \\
\text { effective } \\
\text { marketing/ } \\
\text { production } \\
\text { (for specific } \\
\text { products) }\end{array}$ & $\begin{array}{l}\text { MARKETING/ } \\
\text { INFRASTRUCTURE } \\
\text {-Develop a platform where the } \\
\text { product of the Municipality can } \\
\text { be showcased by online streaming } \\
\text { (ex: OTOP website). } \\
\text {-Source out funding on } \\
\text { machinery/equipment appropriate } \\
\text { for mass production of small } \\
\text { woodcraft items. }\end{array}$ & 2 years & $\begin{array}{l}\text {-Community } \\
\text {-Carvers } \\
\text {-Business } \\
\text { Owners } \\
\text {-Local } \\
\text { Government } \\
\text { Unit } \\
\text {-National } \\
\text { Government }\end{array}$ & $\begin{array}{l}-1 \quad \text { Official } \\
\text { Website for } \\
\text { Paete } \\
\text { Products } \\
\text {-Presence of } \\
\text { at least } 1 \\
\text { Production } \\
\text { Machine/ } \\
\text { Equipment }\end{array}$ \\
\hline $\begin{array}{l}\text { Cooperative } \\
\text { Management } \\
\text { and } \\
\text { Governance }\end{array}$ & $\begin{array}{l}\text {-To sustain the } \\
\text { development } \\
\text { of the wood } \\
\text { carving } \\
\text { industry } \\
\text {-To uphold the } \\
\text { title" Carving } \\
\text { Capital of the } \\
\text { Philippines" }\end{array}$ & $\begin{array}{l}\text { SETTING NETWORKS } \\
\text {-Conduct activities that promote } \\
\text { stakeholders participation } \\
\text {-Uphold in sustaining the title" } \\
\text { Carving Capital of the } \\
\text { Philippines" }\end{array}$ & $\begin{array}{l}\text { All year } \\
\text { round }\end{array}$ & $\begin{array}{l}\text {-Community } \\
\text {-Business } \\
\text { Owners } \\
\text {-Local } \\
\text { Government } \\
\text { Unit } \\
\text {-National } \\
\text { Government }\end{array}$ & $\begin{array}{l}50 \% \text { increased } \\
\text { on LGU } \\
\text { programs and } \\
\text { related } \\
\text { activities } \\
\text { conducted }\end{array}$ \\
\hline $\begin{array}{l}\text { Public } \\
\text { Awareness }\end{array}$ & $\begin{array}{l}\text {-To involve the } \\
\text { community and } \\
\text { young } \\
\text { generations } \\
\text {-To uphold the } \\
\text { title" Carving } \\
\text { Capital of the } \\
\text { Philippines" }\end{array}$ & $\begin{array}{l}\text { INFORMATION } \\
\text { DRIVE/CAMPAIGN } \\
\text {-Conduct information drives to } \\
\text { the public and academe to } \\
\text { sustainably promote the wood } \\
\text { carving industry. } \\
\text {-Step-up public awareness by } \\
\text { elaborating the Town's Festival }\end{array}$ & $\begin{array}{l}\text { At least } \\
\text { annually }\end{array}$ & $\begin{array}{l}\text {-Community } \\
\text {-Local } \\
\text { Government } \\
\text { Unit } \\
\text {-National } \\
\text { Government }\end{array}$ & $\begin{array}{l}50 \% \text { increased } \\
\text { on LGU } \\
\text { programs and } \\
\text { related } \\
\text { activities } \\
\text { conducted }\end{array}$ \\
\hline
\end{tabular}

\section{References}

Adu-Agyem, Joe; Gordon Terkpeh Sabutey and Mensah Emmanuel (2014). Wood Carving in the Akuapem Hills of Ghana: Prospects, Challenges, and the Way Forward. Published by European Centre for Research Training and Development UK. International Journal of Business and Management Review Vol.2, No.1, pp.148-177

Bansal, Pratima \& Desjardine, Mark R. (2014). Business Sustainability: It is about time. Western University, Canada. Strategic Organization, 2014, Vol. 12 (I) 70-78.

Bansal, Tima \& Jardine, Mark (2015), Don't Confuse Sustainability with CSR. Issues: January / February 2015. Categories: IBJ Insights. Retrieved from https://iveybusinessjournal.com/dont-confuse-sustainability-with-csr/ on 02 December 2020 
Baraoidan, Kimmy (2019). Woodcarving Art Alive in Paete. Philippine Daily Inquirer. Retrieved from https://newsinfo.inquirer.net dated April 28, 2019

Battaglia, Massimo, Lara Bianchi, Marco Frey and Emilio Passetti (2015). Sustainability Reporting and Corporate Identity: Action Research Evidence in an Italian Retailing Cooperative. Business Ethics: A European Review Volume 24 Number 1

Clever, Jennifer (2017). Strong Domestic Demand and Declining Production Encourage Wood Imports in 2017. Gain Report - Global Agricultural Information Network.

England, Thomas C. (2018). Why Is Local Economic Development (LED) Key to Sustainable Development? Retrieved from https://www.meandahq.com/why-is-local-economic-development-led-key-to-sustainable-development/ on 30 November 2020.

Gaille, Brandon (2018). 33 Wood Carving industry Statistics, Trends \& Analysis (http://dx.doi.org/10.1016/j.jclepro.2016.06.067)

Gao, Weixia and Jihong Yu (2018). Study on Guang-style Furniture Woodcarving Products and Its CNC Equipment. Published under IOP Conference Series: Materials Science and Engineering. Volume 439, Issue 4

Grant, Michelle (2019). Sustainability. https://www.investopedia.com

Guia, Dian (2016). The Marketing Practices and Economic Viability of Carving Industry of Paete, Laguna. pp. 5-96

Khattak, Sajid Rahman, Saeed , Imran, Tariq, Bilal (2018). Corporate Sustainability Practices and Organizational Economic Performance. Global Social Sciences Review (GSSR) URL: http://dx.doi.org/10.31703/gssr.2018(III-IV).22

Mangra, Mădălina Giorgiana, Elena Antoanela Cotoc, Aurelia Traistaru (2014). Sustainable Economic Development through Environmental Management Systems Implementation. Journal of Studies in Social Sciences ISSN 2201-4624 Volume 6, Number 1, 2014, 1-14 (C) Copyright 2014 the authors. 1 University of Craiova, Romania 2Matei Basarab High School, Craiova, Romania

Marhaeni, A.A.I.N., Ni Nyoman Yuliarmi and Nyoman Djinar Setiawina (2019) Empowering Small Industry of Wood Carving Handicraft in Bangli District. Asia Pacific Journal of Innovation and Entrepreneurship Vol. 13 No. 1, 2019 pp. $121-136$ Emerald Publishing Limited 2398-7812 DOI 10.1108/APJIE-07-2018-0045

Muthini, S. (2017), Small Scale Wood Carving Enterprises and Their Contribution to Rural Livelihoods In Wamunyu, Machakos County, Kenya. Retrieved at https://ir-library.ku.ac.ke.

Lestari, Ni Putu Nina Eka, Made Kembar Sri Budhi, A.A. Ngr. Eddy Supriyadinata Gorda. (2016), The Integration Model of Small Craft Industry Development Strategy of Wood Carving In Bali Province, Indonesia. ISSN 2348-3156 (Print) International Journal of Social Science and Humanities Research ISSN 2348-3164 (online). Vol. 4, Issue 2, pp: (387-393), Month: April - June 2016, Available at www.researchpublish.com

Rezaee, Zabihollah (2016) Business Sustainability Research: A Theoretical and Integrated Approach. Journal of Accounting Literature. http://dx.doi.org

Rilong Fei, Boqiang Lin (2016). Energy Efficiency and Production Technology Heterogeneity in China's Agricultural Sector: A MetaFrontier Approach. Technological Forecasting and Social Change. Volume 109,2016, Pages 25-34, ISSN 0040-1625, https://doi.org/10.1016/j.techfore.2016.05.012.

Stefan Schaltegger, Eric G. Hassen, Florian Ludehe-Freud (2015) Business Models for Sustainability: Origin, Present Research, and Future Avenues, SAGE Publication - Business Models for Sustainability, Entrepreneurship, Innovation, and Transformation.

Shekhawat, Prahlad (2020). The Real Challenges to Sustainable Development. GOVERNMENT/ GLOBAL DEVELOPMENT AGENDA, 22 May 2015. Retrieved from http://www.indiatogether.org/challenges-to-sustainable-development-government on 14 December 2020

Soma, Katrine, Catrien J.A.M. Termeer, Paul Opdam (2016) Informational governance - A systematic literature review of governance for sustainability in the Information Age Environmental Science \& Policy journal homepage: www. Elsevier. com/locate/envsci

The Presidential Proclamation No. 809 (Series of 2005), declared the Municipality of Paete, Laguna, as the "Carving Capital of the Philippines."

UNESCO (2030). Agenda for Sustainable Development Goals. https://en.unesco.org/creativity/sites/creativity/files/247785en.pdf 